УДК 364.3

Колосок Андрій, кандидат економічних наук, доцент, Східноєвропейський національний університет імені Лесі Українки, кафедри економіки, безпеки та інноваційної діяльності підприємства, м. Луцьк; ORCID ID 0000-0001-9167-5430, e-mail: kolosok.andrew@eenu.edu.ua

https://doi.org/10.29038/2411-4014-2020-02-64-71

\title{
СОЦІАЛЬНИЙ ЗАХИСТ ТА СОЦІАЛЬНЕ ЗАБЕЗПЕЧЕННЯ НАСЕЛЕННЯ В УМОВАХ КАРАНТИНУ: ТЕОРЕТИЧНИЙ АСПЕКТ
}

У статті розглянуто економічну сутність категорій «соціальне забезпечення» та «соціальний захист» населення, вказано на проблему ототожнення даних понять, досліджено їх зміст та взаємозв'язок. Відмічено, що категорія «соціальний захист» $\epsilon$ ширшим поняттям, яке включає в себе «соціальне забезпечення». Досліджено особливості соціального захисту населення в умовах карантину на прикладі Волинської області. Відмічено наявні тенденції, проблеми, управлінські помилки органів державної влади та окреслено найблищі перспективи. Запропоновано до використання та дано визначення поняття «гібридний надзвичайний стан». Визначено пріоритетні напрями забезпечення ефективного соціального захисту населення в умовах карантину.

Ключові слова: соціальний захист, соціальне забезпечення, карантин.

Колосок Андрей,

кандидат экономических наук, доцент,

Восточноевропейский национальный университет имени Леси Украинки, кафедры экономики, безопасности и инновационной деятельности предприятия, г. Луцк

\section{СОЦИАЛЬНАЯ ЗАЩИТА И СОЦИАЛЬНОЕ ОБЕСПЕЧЕНИЕ НАСЕЛЕНИЯ В УСЛОВИЯХ КАРАНТИНА: ТЕОРЕТИЧЕСКИЙ АСПЕКТ}

В статье рассмотрено экономическую сущность категорий «социальное обеспечение» и «социальная защита» населения, указано на проблему отождествления данных понятий, исследовано их содержание и взаимосвязь. Отмечено, что категория «социальная защита» является более широким понятием, которое включает в себя «социальное обеспечение». Исследовано особенности социальной защиты населения в условиях карантина на примере Волынской области. Отмечено имеющиеся тенденции, проблемы, управленческие ошибки органов государственной власти и очерчено ближайшие перспективы. Предложено к использованию и дано определение понятия «гибридное чрезвычайное положение». Определены приоритетные направления обеспечения эффективной социальной защиты населения в условиях карантина.

Ключевые слова: социальная защита, социальное обеспечение, карантин.

Kolosok Andrii, PhD in Economics, Associate Professor, Lesya Ukrainka Eastern European National University, Department of Economics, Security and Innovation Activity of the Enterprise, Lutsk

\section{SOCIAL PROTECTION AND SOCIAL SECURITY DURING THE QUARANTINE PERIOD: A THEORETICAL ASPECT}

Introduction. The problems of social protection and social security of the population are particularly acute during the crisis caused by the coronavirus. The shortage of the own financial resources and the difficulties with attracting external credit resources during the global economic slowdown have created new challenges for public authorities, which require complex solutions.

The purpose of the article. The purpose of the article was to substantiate theoretically concepts of "social protection" and "social security", to study the peculiarities of social protection of the population in emergency 
situations. The following research objectives have been identified: to reveal the essence and interrelation of the concepts of "social security" and "social protection"; explore the peculiarities of social protection and social security during the quarantine period.

Results. Having combined and summarized most of the interpretations and approaches, we can say that there is no common accepted definition of the concepts of "social security" and "social protection of the population", as well as the unity of opinion on their composition, structure and methods of expression. Based on the research conducted, we have created our own vision of the nature of these categories and we believe that they are usually incorrectly interpreted. In our view, the category "social protection" is a broader term, which includes "social security".

The authorities of Ukraine were not ready for the social protection and social security of the population under quarantine. Therefore, most of the management decisions in this area were non-systemic and based on the analogy of countries of the European Union not taking into account national peculiarities. Compared to EU countries, there is insignificant financial reserve in Ukraine, miniscule household wealth accumulation, a weak health-care system, significant imbalances in the structure of small and large businesses. In addition, there are significant numbers of migrant workers and socially vulnerable groups, which have created additional risks.

The measures taken by the Cabinet of Ministers to establish an emergency situation throughout the country were controversial from a legal point of view, as they restricted the constitutional rights of citizens without the imposition of a state of emergency.

A significant part of the population was forced to go on leave with no pay, without receiving any compensation from the state to pay for the utility bills. A similar situation has developed in business, operational activities have actually stopped, although taxes and loan obligations must be paid. Such a situation in which the state imposes additional restrictions and obligations on individuals and entities without fulfilling compensation measures in response, we propose to call a "hybrid emergency".

Conclusions. In our opinion, to ensure effective social protection of the population under quarantine, it is necessary: To ensure self-isolation of the population who are at risk (over sixty years old, with chronic diseases, weakened immunity, etc.), without setting the limits on healthy working-age citizens. Organize an effective observation for all citizens arriving from countries with an increased epidemic situation. Produce our own disinfectants, overalls and equipment on preferential taxation terms. Maximize contactless payments (by credit cards, phones with an NFC module) in order to limit cash circulation and reduce the risk of transmission of the virus through banknotes. To do this, it is necessary to stimulate the sphere of contactless payments by loyalty programs both for bank customers and for financial institutions themselves; transfer cash issuance of pensions and other social payments to bank card accounts. Arrange the delivery of vital products and goods to vulnerable categories of the population in order to minimize their presence in public places, using the resources of Ukrposhta and territorial centers of social services. Limit the export of important essential food products, in particular buckwheat, wheat, oil, in order to create their stocks in the country for the long term, and improve social security in the country.

We see the prospects for further research in the development of effective methods of social security under quarantine conditions in order to achieve maximum standards of social protection with a minimum restriction of the rights and freedoms of the population.

Key words: social protection, social security, quarantine.

Постановка проблеми та іï значення. Проблеми соціального захисту та соціального забезпечення населення особливо гостро постали в кризу спричинену короновірусом. Обмаль власних фінансових ресурсів та труднощі із залученням зовнішніх кредитних ресурсів під час світової економічної рецесії, обумовили перед органами державної влади нові виклики, що потребують складних рішень. Додали складнощів і не завершені адміністративна та медична реформа, у зв’язку з чим виникли певні диспропорції у фінансуванні державного та місцевих бюджетів, а ефективне лікування соціально незахищених верств населення потребує ручного керування, особливо в карантинних умовах. Тому дана проблематика є надзвичайно актуальною та потребує швидкого вирішення, оскільки в даних умовах ціною не компетентних рішень $є$ не лише добробут громадян, а й їх здоров’я та життя безпосередньо.

Аналіз останніх досліджень і публікацій. Дослідженням проблем соціального захисту та соціального забезпечення населення в Україні займалися багато вітчизняних вчених, зокрема: Бутрин О. І. [12], Дутчак А. В. [3], рринчишин І. М. [10], Клименко А. Л. [4], Колосок А. М. [5], Міщенко Л. О. [6], Нечипоренко С. Д. [7], Огінська А. Ю. [8], Раневич О. Ю. [9], Сторонянська І. 3. [10], Філіпчук В. Р. [11], Хомин О. Й. [12] та ін. 
Однак, незважаючи на наявність значної кількості наукових праць у цій сфері, соціальний захист та соціальне забезпечення населення потребують подальшого вивчення. Зокрема, існує проблема ототожнення даних понять в повсякденному застосуванні, залишаються недостатньо розробленими теоретико-методологічні питання та практичні рекомендації щодо особливостей здійснення соціального захисту та соціального забезпечення в період карантину.

Мета і завдання статті. Мета статті - обгрунтування теоретичних аспектів понять «соціальний захист» та «соціальне забезпечення», дослідження особливостей соціального захисту населення в умовах надзвичайних ситуацій. Відповідно до поставленої мети, визначено наступні завдання дослідження:

- розкрити сутність та взаємозв'язок понять «соціальне забезпечення» та «соціальний захист»;

- дослідити особливості соціального захисту та соціального забезпечення в період карантину.

Викладення основного матеріалу та обгрунтування отриманих результатів дослідження. Дефініція соціального забезпечення пройшла багато стадій свого розвитку, вона удосконалювалася та все більш глибоко тлумачилася дослідниками. Наразі, не існує єдиного загальноприйнятого визначення поняття «соціальне забезпечення», а також єдності думок щодо їі складу, структури та сфер прояву. Крім того, науковці сперечаються щодо тотожності категорій «соціальне забезпечення» та «соціальний захист», їх взаємозв’язку та підпорядкування.

Зокрема, Дутчак А. В. зазначив що : «соціальне забезпечення є складовою соціальної політики держави та одночасно вважається невід'ємним компонентом системи соціального захисту i соціальної роботи зокрема». На його думку, дану економічну категорію можна визначити «як систему державних і суспільних заходів із матеріального забезпечення громадян на випадок старості, інвалідності, хвороби, в разі втрати годувальника та в інших установлених законодавством випадках» [3, с. 568-569].

Сторонянська I. 3., Гринчишин І. М. дослідили європейський досвід фіскальної децентралізації в контексті розвитку соціального захисту. Зокрема, відмітили «важливість локального рівня публічного управління при фінансуванні видатків соціального забезпечення спрямованих на підтримку людей похилого віку, сімей із дітьми та соціальної інклюзії; зазначили велику відмінність у фінансуванні соціальної сфери в Україні та Європі, як щодо обсягів так і диспропорцій між державним та місцевими бюджетами» [10, с. 27-28].

Нечипоренко С. Д. відмітив, що основою соціального забезпечення є «соціальне страхування, яке представляє собою систему економічних відносин 3 приводу утворення різного виду резервів грошових і матеріальних засобів, необхідних для відшкодування збитку, надання допомоги або для соціального забезпечення в зв'язку з настанням певних подій» [7, с. 59].

Клименко А. Л. розглядала дану категорію згідно стандартів Європейського Союзу, де «соціальне забезпечення віднесено до системи, яка включає, крім соціального забезпечення (через соціальне страхування), також інші форми соціального захисту, зокрема, державну соціальну допомогу, а також спеціальний і особливий (додатковий) соціальних захист для окремих категорій населення» $[4$, с. 8]. Погоджуємося 3 думкою автора, що необхідно поступово реформувати вітчизняну систему соціального забезпечення із метою максимального іiї наближення до відповідних міжнародних стандартів, закріплених у актах Міжнародної організації праці.

Філіпчук В. Р. соціальний захист та соціальне забезпечення розуміє як не розривне ціле, обгрунтовуючи це наявністю у зведеному бюджеті України видаткової статті «Соціальний захист та соціальне забезпечення». Виконання якої реалізується шляхом «призначення пільг, здійснення соціальних та компенсаційних виплат, а також надання соціальних послуг здебільшого державними або комунальними закладами системи соціального захисту» [11, с. 145].

Огінська А. Ю. стверджує, що більшість наявних дефініцій «містять методологічну помилку, адже перерозподільний характер мають лише відносини з соціального страхування, тоді як соціальне забезпечення, що є складовою соціального захисту, доцільно характеризувати як сукупність розподільчих відносин». Підтримуємо дане твердження оскільки, не можливо достовірно визначити, за рахунок яких саме платників податків були сформовані ті частини державного та місцевих бюджетів, які спрямовані на фінансування витрат з соціального захисту населення [8, с. 132].

Міщенко Л. О. притримується думки, «що під соціальним захистом слід розуміти сукупність нормативно закріплених соціальних гарантій спрямованих на вирівнювання положення окремих 
верств громадян, які потребують державної допомоги з іншими у випадках настання соціальних ризиків» не виділяючи окремо категорію соціальне забезпечення [6].

Такої ж думки Хомин О. Й. та Бутрин О. І. : «соціальний захист населення - це діяльність держави, яка скерована на гарантування громадянам їхніх основних соціальних прав завдяки створенню та забезпеченню сприятливих умов для всебічного розвитку населення. Держава повинна не лише гарантувати, а й забезпечувати різним верствам населення певний так званий «пакет» соціальних пільг та гарантій не лише в разі виникнення ризиків чи несприятливих умов проживання, а й взагалі впродовж усього життя» [12, с. 248].

Найбільш повно дану проблематику висвітлив Раневич О. Ю. : «соціальний захист у конституційному його розумінні $\epsilon$ ширшою категорією, аніж соціальне забезпечення, і включає останнє поміж інших структурних елементів. Проте в законодавстві України відсутнє єдине розуміння цих правових понять, що зумовлює юридичну невизначеність і ототожнення конституційно-правових термінів «соціальний захист» i «соціальне забезпечення». Соціальний захист можна визначити як комплекс правових, економічних та організаційних заходів і засобів, покликаних убезпечити як населення загалом, так і окремих індивідів від впливу на них негативних обставин об'єктивного характеру. На відміну від соціального забезпечення, соціальний захист включає й інші соціальні гарантії, що покликані створити умови для нормального життя та розвитку людини, підтримання стану соціальної безпеки та соціальної захищеності ії життя та здоров'я, а також не допустити негативних наслідків у суспільстві й забезпечити соціальну справедливість» $[9$, c. 91].

Розглянемо соціальний захист та соціальне забезпечення в умовах карантину на прикладі Волинської області. Згідно інформації департаменту соціального захисту населення Волинської обласної державної адміністрації в області розпочато виплату соціальних допомог, які перепризначені автоматично в умовах карантину.

Через обмеження та відсутність можливостей безперешкодного доступу до приміщень органів соціального захисту населення в період надзвичайної ситуації державні соціальні допомоги, які призначені та термін яких спливає саме в період карантину, перепризначуються автоматично. До них відносяться : державні соціальні допомоги малозабезпеченим сім'ям, допомоги на дітей одиноким матерям, допомоги сім'ям, які доглядають важкохворих дітей, тимчасові допомоги на дітей, батьки яких ухиляються від сплати аліментів, державні соціальні допомоги особам, які не мають права на пенсію. Законодавчо визначено питання перепризначення виплат на період надзвичайної ситуації усіх соціальних допомог громадянам, в яких на цей час припадає медична перекомісія при встановленні інвалідності. Перепризначення (продовження) допомог на новий термін здійснюється без заяв одержувачів та без інших необхідних документів.

Протягом квітня 2020 року органами соціального захисту населення Волинської області здійснено перепризначення соціальних допомог близько 5 тисячам громадян на загальну суму 21,5 млн. грн. Також протягом даного періоду одноразову виплату в сумі однієї тисячі гривень (в зв'язку із виникненням та поширенням гострої респіраторної хвороби COVID-19), в області отримало близько 17 тисяч окремих категорій громадян. Дані грошові кошти не будуть враховуватись при перепризначені субсидій [1].

Щодо житлових субсидій, то вони перепризначені автоматично на наступний період усім одержувачам, які їх отримували протягом опалювального періоду 2019-2020 років, без їхніх звернень. Крім того збільшенні на 50 \% соціальні нормативи користування окремими комунальними послугами на період дії карантину.

По завершенню карантину органи соціального захисту населення здійснять перерахунок усіх розмірів виплачених допомог, субсидій, пенсій, тощо на підставі поданих заяв та супровідних документів.

Позитивним прикладом соціального захисту населення в умовах карантину $є$ співпраця соціально відповідального бізнесу з органами державної влади. Зокрема, за сприяння Міністерства соціальної політики України та вітчизняної мережі магазинів АТБ надано допомогу продуктовими наборами малозабезпеченим верствам населення Волинської області. Відповідно до розподілу департаменту соціального захисту населення Волинської обласної державної адміністрації протягом карантину 17800 продуктових наборів в магазинах АТБ отримало 18 територіальних центрів, 12 
центрів надання соціальних послуг районів і міст області. До складу продуктового наборів входили життєво необхідні продукти та товари: крупи, макарони, цукор, сіль, рослинні масла, лимони, печиво, чай та інше. Соціальні працівники забезпечили адресну доставку даної натуральної допомоги визначеним соціально незахищеним верствам населення [1]. Така співпраця не тільки забезпечила знедолених продуктами харчування, а й значно зменшила інфікування осіб, що знаходяться у підвищеній зоні ризику.

Благодійний фонд «Тільки разом» витратив на соціальний та медичний захист волинян більше 13 мільйонів гривень. Зокрема, для боротьби 3 розповсюдженням інфекції вразливим верствам населення були роздані продуктові набори на 317 тис. грн.. Для медичних закладів міста Луцька закуплені: 15 тисяч захисник масок та засоби індивідуального захисту й дезінфекції, захисні окуляри, ліки та медичні вироби, 65 сучасних багатофункціональних ліжок та нова постільна білизна, пральне обладнання, бронхофіброскоп та ларингоскоп, термодезінфектор 3 мийними засобами, біохімічний аналізатор, система очищення води та багатофункціональна клінічна центрифуга; змонтовано два потужні компресори системи подачі кисню для апаратів штучної вентиляції легень; встановлено систему кріоциліндрів та бокси з металопластикових конструкцій для унеможливлення контакту хворих з іншими пацієнтами й медичними працівниками; облаштовано бокс для стерильних робіт та ПЛР лабораторію [2]. Причому дані роботи були здійсненні у дуже короткий термін, що значно покращило готовність Волинської області до епідемічної ситуації. Оскільки процедура розподілу та освоєння коштів державного та місцевих бюджетів є досить складною та потребує певного часу навіть у надзвичайному режимі.

Карантин привернув увагу посадовців до соціального захисту медичного персоналу, оскільки заробітні плати в даній сфері мізерні, особливо в молодих лікарів та медсестер. Зокрема, голова Волинської обласної ради зобов’язала комісію з питань бюджету, фінансів та цінової політики підготувати розрахунки для компенсації перевізникам за перевезення медиків, які працюють на обласних комунальних медичних підприємствах і проживають в місті Луцьку та за його межами. А також винайти можливості для додаткового преміювання медичних працівників зайнятих лікуванням хворих на COVID-19 [2].

Необхідно відмітити не готовність місцевих органів державної влади до ефективних управлінських рішень в умовах карантину. Наприклад, на засіданні регіональної комісії 3 питань техногенно-екологічної безпеки та надзвичайних ситуацій, що відбулась під керівництвом голови Волинської облдержадміністрації 9 квітня 2020 року, прийняли додаткові обмежувальні заходи. Зокрема, на вербну неділю, починаючи з 11 квітня з 13.00 до 13 квітня 6.00 в області ввели режим максимального обмеження пересування, влада вказала населенню не виходити з дому та придбати необхідні продукти і ліки заздалегідь [1]. Рекомендаційне рішення місцевої ОДА, не було відповідним чином роз'яснене населенню, що спричинило додаткову паніку та черги у супермаркетах і аптеках, оскільки громадяни подумали, що дані заклади не будуть працювати.

Висновки. Поєднавши та узагальнивши більшість тлумачень та підходів, ми можемо стверджувати, що не існує єдиного загальноприйнятого визначення понять «соціальне забезпечення» та «соціальний захист населення», а також єдності думок щодо їх складу, структури та методів прояву. На основі проведених досліджень ми сформували власне бачення сутності даних категорій та дотримуємось думки про хибність їх ототожнення. На нашу думку категорія «соціальний захист» є ширшим поняттям, яке включає в себе «соціальне забезпечення».

Під «соціальним захистом» ми розуміємо систему взаємопов'язаних економіко-правових заходів направлених на покращення добробуту вразливих верств населення шляхом надання їм пільг, допомог, субсидій, соціальних послуг, страхових виплат, чи можливостей додаткового заробітку 3 метою їх підтримки та створення умов для набуття власної фінансової самодостатності. Кінцевою метою держави у здійснення соціального захисту $є$ зменшення соціального напруження серед населення, заради досягнення високого рівня соціальної безпеки в країні.

Під «соціальним забезпеченням» ми розуміємо гарантовану державою систему матеріального забезпечення населення, яка передбачає страхові виплати громадянам після досягнення ними певного віку, у разі інвалідності, тимчасової непрацездатності, інших випадках передбачених законодавством; утримання будинків-інтернатів та територіальних центрів соціального обслуговування для громадян, які потребують догляду та не мають близьких родичів. 
Органи державної влади України не були готові до соціального захисту та соціального забезпечення населення в умовах карантину. Тому більшість управлінських рішень в цій сфері були безсистемними, та приймалися по аналогії до країн Свропейського Союзу, без врахування національних особливостей. Зокрема, в Україні незначний державний фінансовий резерв, мізерні накопичення домашніх господарств, слабка медична система, значні диспропорції у структурі малого та великого бізнесу в порівнянні з країнами ЄС. Крім того, значна кількість заробітчан та соціально вразливих верств населення, що спричинило значні додаткові ризики.

Прийняті Кабінетом міністрів заходи по впровадженню надзвичайної ситуації на території всієї держави, були суперечливі з юридичної точки зору, оскільки обмежували конституційні права громадян без введення надзвичайного стану. Значна частина населення, була змушена піти у відпустки за свій рахунок, не отримавши від держави жодних компенсацій, щодо оплати комунальних послуг. Аналогічна ситуація склалася у бізнесі, операційна діяльність фактично зупинилася, а податки та кредитні зобов'язання необхідно сплачувати. Такий стан за якого держава накладає на фізичних та юридичних осіб додаткові обмеження та зобов'язання, не здійснюючи у відповідь компенсаційних заходів, ми пропонуємо називати «гібридний надзвичайний стан».

На наш погляд для забезпечення ефективного соціального захисту населення в умовах карантину необхідно:

- Забезпечити самоізоляцію категорій населення, що знаходяться у зоні підвищеного ризику (старші шістдесяти років, з наявністю хронічних захворювань, послабленим імунітетом, тощо), не обмежуючи при цьому здорових працездатних громадян.

- Здійснити перепризначення (продовження) усіх видів соціальних допомог та субсидій на період карантину без будь-яких документів, тобто за відсутності безпосередніх звернень громадян.

- Організувати ефективну обсервацію усіх громадян, що прибувають 3 країн 3 підвищеною епідемічною ситуацією.

- Запровадити виробництво власних дезінфікуючих засобів, спецодягу та обладнання на пільгових умовах оподаткування.

- Максимізувати безконтактні розрахунки (банківськими картами, телефонами з NFC модулем), заради обмеження готівкового обігу та зниження ризиків передачі вірусу через банкноти. 3 цією метою необхідно стимулювати сферу безконтактних розрахунків програмами лояльності як для клієнтів банків так і для самих фінансових установ; перевести готівкову видачу пенсій та інших соціальних виплат на банківські карткові рахунки.

- Налагодити доставку життєво важливих продуктів та товарів вразливим категоріям населення, аби мінімізувати їх присутність у громадських місцях, використовуючи ресурси Укрпошти та територіальних центрів соціального обслуговування.

- Обмежити експорт важливих харчових продуктів першої необхідності, зокрема гречки, пшениці, олії, аби створити їх запаси в країні на довгостроковий період, та покращити соціальну безпеку країни.

- Проводити на загальнодоступних інформаційних ресурсах постійну роз'яснювальну роботу, щодо рішень органів державної та місцевої влади пов'язаних з обмеженням пересування населення та здійснення карантинних чи санепідеміологічних заходів, аби уникнути паніки, ажіотажу та черг за продуктами першої необхідності.

- Створити чітку інструкцію щодо порядку госпіталізації хворих, та осіб підвищеного ризику зокрема, як на загальнодержавному так і місцевому рівнях. Вказати необхідний список речей, продуктів, ліків, засобів захисту, фінансових ресурсів, тощо, які громадянам рекомендовано мати наготовленими на випадок госпіталізації їх чи близьких родичів.

- Заборонити проїзд у громадському транспорті особам, що знаходяться у зоні підвищеного ризику (пенсіонерам, хронічним хворим, тощо), інші категорії населення перевозити лише в засобах індивідуального захисту та з розрахунку одна особа на два квадратних метра транспортного засобу.

- Обмежити богослужіння усіх конфесій, перевести їх в он-лайн режим, заборонити присутність мирян у храмах до повного завершення карантину. Особливо важливо не допустити скупчення віруючих під час релігійних свят вербної неділі, Пасхи, тощо. 
- Забезпечити безкоштовний проїзд медичного персоналу, до місць роботи та у зворотному напрямку, виділити кошти на харчування медперсоналу, які лікують хворих на COVID-19 в умовах обсервації.

Перспективи подальших досліджень убачаємо в розробці ефективних методів соціального забезпечення в умовах карантину, аби при мінімальному обмеженні прав і свобод населення досягнути максимальних стандартів соціального захисту.

\section{Джерела та література}

1. Волинська обласна державна адміністрація. URL : https://voladm.gov.ua/ (дата звернення: 15.04.2020).

2. Волинська обласна рада. URL : http://volynrada.gov.ua/ (дата звернення: 16.04.2020).

3. Дутчак А. В. Соціальне забезпечення громадян: сучасний стан та перспективи розвитку. Молодий вчений. 2017. № 5 (45). С. 568-571.

4. Клименко А. Л. Соціальний захист і соціальне забезпечення в умовах євроінтеграції України: окремі аспекти. Теорія і практика правознавства. 2017. № 2 (12). С. 1-10.

5. Колосок А. М. Соціальний захист населення: актуальні проблеми та перспективи розвитку. Економічний часопис Східноєвропейського наиіонального університету імені Лесі Украӥнки. 2019. №17. С. 38 45. DOI: https://doi.org/10.29038/2411-4014-2019-01-38-45

6. Міщенко Л. О. Сучасний стан соціального захисту та соціального забезпечення населення в Україні в умовах децентралізації: напрями подальшого розвитку. Ефективна економіка. 2017. № 11. URL: http://www.economy.nayka.com.ua/?op=1\&z=5867

7. Нечипоренко С.Д. Сутність та значення соціального страхування в системі соціального захисту населення. Агросвіт. 2017. № 6. С. 55-60.

8. Огінська А. Ю. Соціальний захист населення та фінансовий механізм його реалізації: теоретикоконцептуальний зріз. Економіка та держава. 2018. № 4. С. 131-136.

9. Раневич О. Ю. Про використання термінів «соціальний захист» i «соціальне забезпечення» в нормативно-правових актах України. Підприємництво, господарство і право. 2017. № 9. С. 88-92.

10. Сторонянська I. 3., Гринчишин I. М., Дуб А. Р, Хорга Й. Фіскальна децентралізація в Європі в контексті розвитку соціального захисту. Економічний часопис-ХХI. 2019. № 175 (1-2), С. 24-28. DOI: https://doi.org/10.21003/ea.V175-04

11. Філіпчук В. Р. Тенденції та проблеми фінансового забезпечення соціального захисту населення за умов глобалізації. Причорноморські економічні студії. 2018. № 31, С. 141-147.

12. Хомин О. Й., Бутрин О. І. Соціальний захист населення: суть поняття та еволюція. Науковий вісник Львівського державного університету внутрішніх справ. Серія економічна. 2015. № 1, С. 245-254.

\section{References}

1. Volynska oblasna derzhavna administratsiia [Governor of Volyn Oblast]. (n.d.). voladm.gov.ua. Retrieved from http://voladm.gov.ua/ [In Ukrainian].

2. Volynska oblasna rada [Volyn Regional Council]. (n.d.). volynrada.gov.ua. Retrieved from http://volynrada.gov.ua/ [In Ukrainian].

3. Dutchak, A.V. (2017) Cotsialne zabezpechennia hromadian: suchasnyi stan ta perspektyvy rozvytku. [Public social security: current state and prospects of development]. Molodyi vchenyi - Young Scientist, 5 (45), 568-571 [in Ukrainian].

4. Klymenko, A. L. (2017) Sotsialnyi zakhyst i sotsialne zabezpechennia v umovakh yevrointehratsii Ukrainy: okremi aspekty [Social protection and social security in the conditions of Ukraine's Eurointegration: selected aspects]. Teoriia i praktyka pravoznavstva - Theory and practice of jurisprudence. 2 (12), 1-10 [in Ukrainian].

5. Kolosok, A. M. (2019) Sotsialnyi zakhyst naselennia: aktualni problemy ta perspektyvy rozvytku [Social protection of population: actual problems and prospects of development]. Ekonomichnyi chasopys Skhidnoievropeiskoho natsionalnoho universytetu imeni Lesi Ukrainky - Economic Journal of Lesia Ukrainka Eastern European National University, 17, 38-45. DOI: https://doi.org/10.29038/2411-4014-2019-01-38-45 [In Ukrainian].

6. Mishchenko, L. O. (2017) Suchasnyi stan sotsialnoho zakhystu ta sotsialnoho zabezpechennia naselennia v Ukraini v umovakh detsentralizatsii: napriamy podalshoho rozvytku [The current state of social protection and social security of the population in Ukraine in conditions of decentralization: directions of further development]. Efektyvna ekonomika - Efektyvna ekonomika, 11. Retrieved from http://www.economy.nayka.com.ua/?op=1\&z=5867 [in Ukrainian]. 
7. Nechyporenko, S. D. (2017) Sutnist ta znachennia sotsialnoho strakhuvannia v systemi sotsialnoho zakhystu naselennia [The essence and importance of social insurance in the social protection system]. Ahrosvit -Agrosvit. 6, 5560 [in Ukrainian].

8. Ohinska, A. Yu. (2018) Sotsialnyi zakhyst naselennia ta finansovyi mekhanizm yoho realizatsii: teoretykokontseptualnyi zriz [Social protection of the population and financial mechanism of its realization: theoretical and conceptual section]. Ekonomika ta derzhava - Ekonomika ta derzhava, 4, 131-136 [in Ukrainian].

9. Ranevych, O. Yu. (2017) Pro vykorystannia terminiv «sotsialnyi zakhyst» i «sotsialne zabezpechennia» v normatyvno-pravovykh aktakh Ukrainy [On the use of the terms «social protection» and «social security» in the legal acts of Ukraine]. Pidpryiemnytstvo, hospodarstvo i pravo - Entrepreneurship, Economy and Law, 9, 88-92 [in Ukrainian].

10. Storonianska, I. Z., Hrynchyshyn, I. M., Dub, A. R, \& Khorha, Y. (2019) Fiskalna detsentralizatsiia v Yevropi $\mathrm{v}$ konteksti rozvytku sotsialnoho zakhystu [Fiscal decentralization in Europe in the context of social protection development]. Ekonomichnyi chasopys- XXI - Economic Annals-XXI, 175(1-2), 24-28 DOI: https://doi.org/10.21003/ea.V175-04 [in Ukrainian].

11. Filipchuk, V. R. (2018) Tendentsii ta problemy finansovoho zabezpechennia sotsialnoho zakhystu naselennia za umov hlobalizatsii \&Trends and problems of financial provision of social protection of the population under globalization conditions]. Prychornomorski ekonomichni studii - Black sea economic studies, 31, 141-147 [in Ukrainian].

12. Khomyn, O. J., \& Butryn, O. I. (2015) Sotsialnyi zakhyst naselennia: sut poniattia ta evoliutsiia [Social protection of population: the essence of the concept and evolution]. Naukovyi visnyk Lvivskoho derzhavnoho universytetu vnutrishnikh sprav. Seriia ekonomichna. - The Scientific Bulletin of Lviv State University of Internal Affairs (economic series), 1, 245-254 [in Ukrainian]. 